\title{
Analisis Trauma Masa Lalu Tokoh Sari dalam Novel "Wanita Bersampur Merah" Karya Intan Andaru: Kajian Psikologisastra
}

\author{
Ika Nurdayana $^{1}$, Ekarini Saraswati ${ }^{2}$ \\ Pendidikan Bahasa dan Sastra Indonesia Fakultas Keguruan dan Ilmu Pendidikan, \\ Universitas Muhammadiyah Malang \\ Ikandfhm123@gmail.com ${ }^{1}$, ekarini@umm.ac.id ${ }^{2}$
}

DOI: https://doi.org/10.32528/bb.v5i2.3011

\begin{abstract}
ABSTRAK
Penelitian ini memiliki tiga tujuan pertama, menguraikan trauma masalalu yang dialami oleh tokoh Sari. Kedua, mendeskripsikan bentuk trauma yang dialami tokoh Sari. Ketiga, menganalisis bentuk penguatan yang terdapat dalam novel "Wanita bersampur Merah". Untuk mengupas permasalahan trauma yang dialami oleh tokoh Sari dalam novel "Wanita Bersampue Merah" digunakan pendekatan psikologisastra dengan konsep psikologi Behaviorisme Skinner . Jenis penelitian yang digunakan adalah penelitian kualitatif.Teknik yang digunakan padaadalah teknik baca catat,serta analisis data yang digunakan adalah deskriptif analitik. Sumber data pada penelitian ini yaitu, novel "Wanita Bersampur Merah" Hasil penelitian ini ditemukan sub pembahasan pertama, ditemukan dua faktor yang melatarbelakngi trauma yang dialami oleh tokoh Sari yakni , (1) Pembunuhan , (2) Diskriminasi. Kedua ditemukan bentuk trauma yang dialami oleh tokoh Sari yakni, (1) Ketakutan Pada Dunia Luar, (2) Kecemasan Tokoh Sari pada Bahaya yang ditemui pada masalalunya. Ketiga, ditemukan du bentuk penguatan yang ada pada diri tokoh sari untuk memulihkan trauma masa kecilnya yakni, (1) Penguatan positif, (2) Penguatan Positif bersifat tetap.
\end{abstract}

Kata Kunci: Trauma; Penguatan; Psikologi Sastra; Behaviorisme

\begin{abstract}
This research has three objectives, first, to describe the past trauma experienced by the character Sari. Second, describe the form of trauma experienced by Sari's character. Third, analyzing the form of reinforcement contained in the novel "Wanita with Red". To discuss the problem of trauma experienced by Sari's character in the novel "Wanita Bersampue Merah", a literary psychological approach with the concept of Skinner's Behaviorism is used. This type of research is qualitative research. The technique used is the reading note technique, and the data analysis used is descriptive analytic. The data source in this study is the novel "Wanita Bersampur Merah". The results of this study were found in the first sub-discussion, two factors were found behind the trauma
\end{abstract}


experienced by Sari's character, namely, (1) Murder, (2) Discrimination. Second, the form of trauma experienced by Sari's character is found, namely, (1) Fear of the Outside World, (2) Anxiety of Sari's Character in the Danger that he finds in his past. Third, found two forms of reinforcement that exist in sari figures to recover from childhood trauma, namely, (1) positive reinforcement, (2) positive reinforcement is permanent.

\section{Keywords: Trauma; Reinforcement; Literary Psychology; Behaviorism}

\section{PENDAHULUAN}

Psikologi merupakan salah satu disiplin ilmu yang memiliki fokus aspek kejiwaan pada manusia. Sejalan dengan perkembangan zaman adapun perpaduan ilmu yang berkolaborasi menjadi satu salah satunya psikologi sastra merupakan bentuk interdisipliner, adanya kedua ilmu yang memadukan kesatuan menjadi psikologi dan sastra (Rokhmansyah, 2014). Ilmu Psikologi dan Sastra merupakan dua disiplin ilmu yang berbeda akan tetapi dari perbedaan tersebut , tidak terlelpas kemunkinan untuk saling mlengkapi satu sama lain. Kemungkinan yang menyatukan ilmu Peiskologi dan Sastra terletak pada, sastra yang tidak dapat jauh dari ilmu psikologi karena dalam unsur suatu karya sastra tidak terlepas yang sangat kaya akan aspek kejiwaan didalamnya (Elisaa, 2016 hal. 35)

Sastra memiiliki ciri khas yang berbicara tentang rasa. Rasa yag terdapat pada sastra adalah rasa yang lekat denga pribadi. Pada dasarnya yang menjadi objek dari psikologi sastra adalah aspek kemanusiaan yang ada pada diri tokoh fiksional yang terdapat dalam sebuah karya sastra yang diciptakan (Rokhmansyah, 2014 hal 32-34).

Karya sastra yang hadir dan dinikmati bersumber dari sebuah cetusan ide dan kreatifitas seorang pengarang yang dituangkan melalui tulisan yang merepresentasikan secara keseluruhan kehidupan sosial dalam masyarakat (Syifa, 2015, hal. 5). Proses penciptaan suatu karya pada seorang pengarang tidak sembarangan dalam proses menuangkan idennya dalam proses penciptaan suatu karya sastra. Dalam proses penciptaanya seorang pengarang melakukan komunikasi pada lingkungan sosial baik secara sengaja atau disengaja dengan masyarakat sekitarnya sehingga, memproleh pengalaman, dan fakta sosial, dan permasalahan yang dirangkai menjadi sebuah karya sastra yang memiliki nilai estetika (Faruk, 2017, hal. 45). Nilai estika yang terdapat pada suatu karya sastra merupakan penggabungan antara jiwa pengarang dengan kesadaranya yang terdapat dalam dirinya yang berkolaborasi menjadi sebuah karya.

Permasalahan yang diangkat dalam novel biasanya tidak luput dari terjadinya permasalahan yang terjadi pada tokoh utama maupun tokoh sentral lainya. Sejalan dengan pemaran di atas adapun permasalahan yang diangkat dalam novel "Wanita Bersampur Merah" karya Intan Andaru adalah mengisahkan trauma yang dialami oleh tokoh Sari, karena ketakutan pada masa kecilnya yang diakibatkan oleh, kerusuhan yang terjadi di Banyuwangi pada tahun 1998 yang menewaskan Ayahnya. Novel yang berjudul "Wanita Bersampur Merah " merupakan salah satu karya sastra yang di tuis oleh Intan Andaru. Penulis novel "Wanita Bersampur Merah" merupakan salah seoramg penulis yang dilahirkan di Kota Banyuwangi. 
Pemilihan karya sastra pada penelitian ini didasasri adanya Post Traumatic Stress Disorder yang dialami oleh tokoh Sari dan keluarganya dialami diakibatkan oleh kelompok mastyarakat disekitarnya yang terdapat pada novel "Wanita Bersampur Merah" karya Intan Andaru. Bermulanya trauma yang tokoh Sari dilatarbelakangi dari kejadian pembantaian dukun santet yang terjadi di kampunya pada tahun 1998 menjadi pemicu utama trauma. Peristiwa pembantaian dukun sasntet yang menewaskan Ayahnya, yang secara tidak langsung memberikan pengaruh selalu memikirkan kejadian traumatis ini sepanjang waktu dan hal ini dapat mempengaruhi kehidupannya.

Trauma jenis Post Traumatic Stress Disorder merupakan, salah satu jenis trauma yang terjadi karena karena pengaruh dari masalau dalam kehiduapan. Menurut American Psychiatric Asssociation (1994), memaparkan Post Traumatic Stress Disorder merupakan trauma yang terjadi pada suatu keadaan mental yang sering mengalami serangan panik yang diakibatkan oleh trauma pengalaman yang terjadi pada masalalunya (Tentama, 2014, hal.134). Efek dari terjadinya, gagngguan stress pasca trauma jenis ini, mengakibtakan tokoh Sari sulit untuk menyesuaikan diri dan menerima perubahan setelah kejadian traumatis yang terjadi dalam kehidupan, adapun celah yang mebuat seorang penderita trauma ini menjadilebih baik dari keadaan sebelumnya.

Penelitian ini penting untuk dilakukan karena, topik yang di sajikan pada kajian ini belum pernah disinggung pada penelitian terdahulu. Penelitian ini memiliki tiga tujuan. Pertama, mennguraikan trauma masalalu yang dialami oleh tokoh Sari. Kedua, mendeskripsikan bentuk trauma yang dialami tokoh Sari. Ketiga menganalisis bentuk penguatan yang terdapat dalam novel "Wanita bersampur Merah". Penelitian ini menarik untuk dilakukan karena, topik yang dibahas bersumber dari novel "Wanita Besampur Merah" karya Intan Andaru tersebut merupakan kisah nyata seorang tokoh bernama Sari yang kehilangan Bapaknya karenan menjadi korban pembantaian dukun santet tahun 1998 di Banyuwangi. Novel "Wanita Bersampur Merah" yang ditulis oleh, Intan Andaru mengangkat suatu permasalahan yang menceritakan kejadian masa kelam di Banyuwangi.

Penceritaan yang diangkat salah satunya, dibawakan oleh tokoh Sari yang mengalami trauma dialami tokoh Sari dan keluarganya. Terjadinya trauma tersebut, beawal dari kejadian pembataian dukun santet 1998 dan setelah tragedi pembantaian tersebut mengalami gangguan stress yang mengakibatkan ketakutan pada dunia sekitarnya. Permaslahan ini belum banyak diketahui oleh masyarakat luas, dan belum dibahas dansinggung pada penelitian terdahulu.

Sejauh penulusuran pustaka penulis, belum menemukan penelitian yang mengkaji Novel "Wanita Bersampur Merah". Adapun penelitian sejenis yang membahas permasalahan trauma. Penelitian pertama dilakukan oleh, Labista (2015) dengan judul Dampak Psikologis Tokoh Sumida Yuchi Dan Ma-kun Pasca Gempa Bumi dan Tsunami Sendai 2011 Dalam Film Himizu Karya Sutradara Sono Sion. Penelitian ini dilakukan untuk memenuhi syarat kelulusan atau Skripsi strata satu Sastra Jepang.

Pendekatan psikologi sastra yang digunakan peneliti pada penelitian ini memiliki fokus pada penelitian ini berupa, menelaah dampak pskilogis tokoh Sumida Yichi dan 
Ma-kun. Penelitian kedua, dilakukan oleh, Yohana (2012) dengan judul Trauma Tokoh Nayla dalam Novel Karya Djenar Maesa Ayu. Penelitian yang dilakukan beryujuan untuk memenuhi syarat kelulusan memenuhi Strta Satu. Fokus penelitian untuk mengetahui pengaruh trauma yang terjadi pada tokoh utama (Nayla) pada kepribadian dan kehidupannya sebagai seorang pengarang. Adapun teori yang digunakan sebagai pisau pemecah permasalahan pada penelitian ini adalah Psikoanalisis Sigmun Freud.

Ketiga, penelitian ini dilakukan oleh, Dewiana (2011) dengan judul Analisis Truma Dan Dendam Hannibal lecter dalam Novel Hannibal Rising Karya Thomas Harris. Penelitian ini dilakukan untuk memenuhi syarat kelulusan Sastra Inggris. Penelitian memiliki titik fokus pada perubahan karakter yang terdapat pada tokoh Hannibal Lecter dalam novel Hannibal Rising perubahan karakter tersebut sesuai dengan teori Psikoanalisis yang dipapakan oleh, Sigmund Freud. Berbeda dengan penilitian terdahulu. Fokus penelitian ini meyoroti 3 aspek permasalahan pertama, faktor-faktor yang menyebabkan trauma yang dialami tokoh Sari. Kedua, menganalisis bentuk trauma yang dialami Sari dan keluarganya. Ketiga menganalisis bentuk penguatan tokoh Sari yang terdapat dalam novel "Wanita bersampur Merah".

Pendekatan yang digunakan pada penelitian ini adalah pendekatan psikologi sastra. Psikologi adalah salah satu itu ilmu yang memiliki fokus aspek kejiwaan manusia. Psikologi sastra merupakan bentuk interdisipliner dua ilmu yang berbeda yang membaur mebentuk sastu kesatuan, yaitu psikologi dan sastra. Ilmu psikologi dan satra berlainan akan tetapi, tidak terlelpas dari kemunkinan untuk saling mlengkapi. Sastra merupakan salah satu ilmu humaniora yang tidak bisa terlepas dari peranan ilmu psikologi. Kedua ilmu tersebut memiliki keterkaitan dalam sebuah karya yang sangat kaya akan aspek kejiwaan didalamnya (Nofitra, 2017 hal.75) .

Sastra memiliki satu kencendrungan berbicara tentang rasa. Rasa yang dimaksud dalam sastra adalah rasa yang lekat dengan pribadi manusia. Pada dasarnya yang menjadi objek dari sastra adalah manusia yang ada pada diri tokoh di dalam sebuah karya sastra yang diciptakan oleh pengarang. Teori yang digunakan untuk pisau pemecah permasalahan pada penelitian ini adalah Psikologi Behaviorisme Skinner. Penggunaan teori ini dijadikan sebagai pisau pemebedah dari permasalahan trauma masa kecil yang terjadi tokoh Sari. Berdasarkan latar belakang diatas terdapat tiga pokok permasalahan yang dibahas pada penelitian ini meliputi 1.Bagaiamana faktorfaktor yang mempengaruhi trauma tokoh Sari dan keluarganya ?. 2. Bagaimana bentuk bentuk trauma yang dialami tokoh Sari dan keluarganya.

Penelitian ini bertujuan untuk Menganalisis faktor-faktor yang menyebabkan trauma yang dialami oleh tokoh Sari dan keluarganya, mendeskripsikan bentuk trauma yang dialami tokoh Sari dan menganalisis bentuk penguatan yang terdapat dalam novel "Wanita bersampur Merah". 3. Bagaimana bentuk penguatan tokoh Sari yang terdapat dalam novel "Wanita bersampur Merah". Sejalan dengan pemaparan di atas , untuk menjawab tujuan dari penelitian ini digunakan pendekatan psikologi sastra dengan persepektif psikologi behaviorisme Skinner. 


\section{METODE PENELITIAN}

Penelitian ini menggunakan jenis penelitian kualitatif karena data yang digunakan berupa bentuk kalimat -kalimat,tidak berupa angka. Pendekatan yang digunakan dalam mengkaji novel "Wanita Bersampur Merah" karya Intan Andaru adalah pendekatan Penelitian ini dilakukan menggunakan pendekatan psikologi sastra. Psikologi sastra merupakan salah satu pendekatan dua ilmu anatara psikologi dan sastra. Psikologi sastra memiliki asumsi bahwasanya suatu karya sastra mrmilkiki kerkaitan dengan unsur-unsur kejiwaan tokoh-tokoh fiksional yang terkandung di dalamnya (Syifa, 2015, hal. 4).

Instrumen penelitian yang digunakan untuk mengkaji novel "Wanita Bersampur Merah" karya Intan Andaru yaitu, human instrumen (penelitian sendiri). Pada dasarnya , penelitian kualitatif human instrumen, peneliti sendiri yang bertindak sebagai instrumen penelitian. Human Instrumen ini digunakan bertujuan untuk memperoleh data pada penilitian yang valid dan berfokus pada tujuan penelitian sehingga, hasil penelitian yang dilakukan dapat dipertangungjawabkan. Alat bantu yang digunakan untuk menelaah novel "Wanita Bersampur Merah" karya Intan Andaru meliputi buku teori yang berkaitan dengan fokus penelitian. Media teknologi yang digunakan untuk mengakses jurnal penelitian yang berkaitan dengan masalah penelitian. Adapun alat bantu pada penelitian ini adalah kartu data yang berfungsi untuk mencatat dan mendiskripsikan seluruh data yang diperoleh.

Sumber data yang digunakan pada penelitian ini adalah novel "Wanita Bersampur merah" karya Intan Andaru yang diterbitkan pada tahun 2019 dengan ketebalan buku 206 halaman. Data yang dikumpulkan pada penelitian ini berupa dialog antar tokoh dan narasi yang terdapat pada novel "Wanita Bersanpur Merah" yang memiliki hubungan dengan rumusan masalah dan mencakup konteks truama yang dialami oleh Sari yang disebabkan oleh kelompok masyarakat di kampungnya karena isu lokal santet dan pembantaian dukun di Banyuwangi tahun 1998. Teknik pengumpulan data yang digunakan pada penelitian ini teknik baca catat.

Teknik baca catat diaplikasikan dengan cara membaca seluruh isi novel "Wanita Bersampur Merah" karya Intan Andaru secara berulang-ulang kemudian , menandai atau memncatat data yang sesuai dengan tujuan penelitian. Langkah-langkah dalam pengumpulan data tersebut antara lain. Pertama membaca novel "Wanita Bersampur Merah" karya Intan Andaru secara berulang. Kedua, membacadan mempelajari seluruh literatur, referensi dan pustaka yang berkaitan dengan masalah penilitian . Ketiga, mencatat data yang sesuai dengan rumusan masalah dari beberapa kutipan novel "Wanita Bersampur Merah" karya Intan Andaru. Keempat, mengelompokkan dan membuat kode data yang sesuai dengan rumusan masalah.

Teknik analisis penelitian ini adalah teknik deskriptif analitik. Deskriptif analitik adalah suatu teknik yang digunakan untuk mendeskripsikan fakta-fakta yang terdapat objek penelitian kemudian, dilanjutkan dengan menguraikanya sampai dengan tahap memberikan pemahaman dan penjelasan (Ratna, 2012, hal. 53).Pengecekan keabsahan data pada penelitian ini yaitu, triangulasi (sumber data dan teori). Peneliti melakukan 
diskusi dengan teman sejawat yang bertujuan untuk memeriksa kevalidan data, adanya cara tersebut dapat mempermudah peneliti dalam proses pengecekan keabsahan data.

\section{PEMBAHASAN}

Novel "Wanita Bersampur Merah" merupakan salah satu karya sastra yang mengangkat permasalahan isu lokal santet yang mengakibatkan terjadinya, pembantaian dukun santet dan teror yang dilakukan ninja, berlangsung di Banyuwangi pada tahun 1998 yang ditulis oleh, Intan Andaru.

Novel "Wanita Bersampur Merah" mengkisahkan kehidupan masa kecil tokoh Sari yang kehilangan bapaknya yang menjadi korban pembantaian pembersihan dukun santet pada bulan september 1998. Dalam pengkisahan novel "Wanita Bersampur Merah" diceritakan tragedi pembantaian yang terjadi pada tahun 1998 merupakan kisah kelam yang dialami oleh, seluruh masyarakat Banyuwangi. Teror yang dilakukan oleh ninja yang membunuh guru njaji dan pemuka agama aktivis Ham yang terjadi di pada bulan oktober 1998.

\section{Faktor-Faktor Trauma Yang Di Alami Tokoh Sari Dalam Novel "Wanita Bersampur Merah"}

\section{1) Pembunuhan}

Pembunuhan merupakan tindakan kriminal yang sengaja dilakukan untuk menghilangkan nyawa lawannya. Berikut kutipan yang menggambarkan kejadian pembunuhan yang terjadi pada teman karib dari bapak tokoh Sari terdapat pada novel "Wanita Bersampur Merah".

Seketika bapak memegangi kepalanya dengan tangan seolah-olah
ada berton-ton batu pada tempurung keplanya." Mereka telah
dibunuh. Ndak cuma Pak Muhidin,tapi anak dan istrinya juga.
Mayatnya.." Bapak mulai menarik napas yang dalam lantas
menggeleng, matanya terpejam, (Hal. 59-60 Bab.10 Prgf.6).

Berdasarkan kutipan narasi dan dialog diatas menggambarkan adanya perencanaan pembunuhan yang dilakukan kelompok masayarakat kepentingan yang ingin menghabisi nyawa Pak Muhudin yang tidak lain teman dari Bapak Sari. Tokoh bapak Sari tewas dituduh menjadi dukun santet di kampungnya. Pada tahun 1998 khusunya buklan agusutus sampai dengan september masyarakat yang ada di pelosok hingga kota Banyuwngi gencar-gencarnya memburu orang-orang disekitarnya yang memiliki keahlian magis.

Akan tetapi pada kenyataannya dukun-dukun yang terbunuh pada saat kejadian tersebut tidak diberikan kesempatan untuk membela dirinya sedangkan, kelompok masyarakat kepentingan telah bersepakat dengan tujuan awalnya yaitu, menghilangkan nyawa dari terdakwa tersebut. Maksud masyrakat berkepentingan adala masyrakat yang memilki kepentingan terselubung dalam aksi tersebut. 
Hasil analisis kutipan narasi dan dialog diatas memberikan gambaran nyata dimana pembunuhan yang dialami oleh keluarga Pak Muhidin yang di latarbelakangi adanya hubungan yang tidak harmonis yang bersumber dari adanya isu santet mengakibatkan adanya konflik yang memicu terjadinya pembunuhan yang dilakukan kelompok masyarakat kepentingan yang tidak memimikirkan moral yang ada pada kehidupan dan memahami hubungan harmonis yang sudah terjalin (Kohlberg \& Hersh, 19973 ). Pembuuhan berencana yang dilakukan masyarakat di tahun 1998 merupakan bentuk tindakan pidana yang didalamnya mengandung unsur kesengajaan meleyapkan nyawa sesama manusia. Pembunuhan yang menimpa tokoh bapak Sari tersebut didasari hilangnya ajaran moral yang ada pada diri masyarakat (Sukardi,2016:76).

Kasus pembunuhan yang terjadi pada tokoh Pak Muhiddin yang tertuduh sebagai dukun santet mencerminkan bentuk perubahan sikap masyarakat yang karena, adanya isu santet dan fitnah yang beredar serta menyebabkan pertentangan antara kelompok masyarakat dan masyarakat yang tertuduh sebagai dukun santet. Pembunuhan yang terjadi pada tahun 1998 dilakukan secara terang-terang didepan muka umum, pembunuhan ini dilakunan dengan cara mencekik dan memukul korban secara bergantian maupun digorok dengan senjata tajam yang dilakukan ditempat tersembunyi seperti kebun, persawahan dan bukit.

\section{2) Diskriminasi}

Tindakan diskriminasi dalam kehidupan sosial terdapat bermacam-macam bentuk perlakuan salah satunya, adaalah adanya suatu bentuk perlakuan tidak adil dalam kehidupan berawal dari timbulnya prasangka, seorang individu merasa mendapatkan perlakuan tidak adil dari orang-orang yang ada disekitarnya. Diskriminasi yang terjadi pada kehidupan tokoh Sari mengakibatkan efek psikologis yang tidak baik untuk keadaan psikologis tokoh Sari.

Aku dapat memahaminya sebab kadang aku pun merasa sedih tinggal dikampung ini. Terlebih akhir-akhir ini, ketika aku telah mencoba memaafkan apa yang terjadi, beranjak dewasa,dan mulai mengenal cinta ,beberapa dari mereka bahkan masih bicara "Jangan menikahinya, Ia anak dukun santet”. (Hal.9 Bab.1 Prgrf.1).

Pada kutipan narasi diatas memperkuat adanya diskriminasi yang diterima oleh Sari dan keluarganya. Bentuk diskriminasi yang dialami oleh,tokoh Sari dan keluarganya ditandai dengan adanya identitas khusus,yang diberikan kelompok masyarakat yang menentang eksistensi dukun santet yang ada didaerahnya. Identitas yang diberikan masyarakat pada tokoh Sari tersebut, berupa julukan dan stigma negatif sebagai anak dukun santet. Adanya julukan tersebut mengakibatkan perasaan yang ada dalam diri tokoh Sari yang merasa tidak mendapatkan perakuan tidak adil dan kesetaraan di lingkungannya yang mengakibatkan terjadinya trauma pada tokoh Sari.

Hasil analisis pada data diatas memperkuat diskriminasi yan terjadi pada tokoh Sari mengakibatkan adanya kerugian fisik dan mental yang harus diterima. Penyebab 
dari diskriminasi yang diterima oleh keluarga Sari bersumber dari adanya corak sosialisasi fenomena,yang berkembang dan diwariskan turun-temurun pada kelompok masyarakat ada di Banyuwangi, sehingga pada saat sedang gencar-gencarnya dengan isu lokal satet. Kerugian fisik yng dimaksud tersebut berupa pertumpahan darah yang mengakibatkan tokoh Bapak Sari harus kehilangan nyawanya, sedangkan kerugian mental tersebut berupa adanya trauma yang ada pada tokoh Sari berupa adanya diskriminasi (Hanurawan, 2011).

Diskriminasi yang didapatkan berupa pemberian identitas khusus yang disandang masayarakat korban dari adanya pembantaian, identitas tersebut, akan melekat seumur hidup yang mengakibakan adanya stigma khusus khusus yang melekat paf sepajang hidupnya. Selain identitas masyaarakat yang sampai saat ini juga memberikan perlakuan khusus yang menyudutkan keluarga korban pembantaian sehingga mengakibatkan adanya ketidaksetaraan yang diterima pada kehidupan sehari-hari.

\section{Trauma Yang Di Alami toko Sari Dalam Novel "Wanita Bersampur Merah"}

Lingkungan merupakan faktor yang mempengaruhi dasar tebentuknya tarauma yang terjadi pada tokoh Sari yang bersamaan dengan adanya kecemasan atau ketakutan yang dialmi ole setiap seseorang yang mengalami trauma. Berikut data yang menunjukkan bentuk-bentuk trauma yang dialami oleh tokoh Sari Sebagai berikut.

\section{1) Ketakutan Pada Dunia Luar}

Dunia luar merupakan lingkungan yang terdapat pada lingkungan luar asuh dari keluarga. Lingkungan luar atau dunia luar merupakan lingkungan yang menjadi tempat berlangsungnya interkasi yang terjadi di lingkungan masyarakat. Ketakutan pada dunia luar merupakan salah satu bentuk dari adanya trauma yang terjadi oleh toko Sari. Berikut data yang merepresentasikan trauma pada dunia pada tokoh Sari.

\section{Tiap kali aku melihat keluar rumah, aku sungguh masih dapat merasakan kejadian malam itu: Ingatan ku tentenag segerombolan orang yang mengepung rumah. (Hal.70)}

Hasil analisis dari data diatas memeperkuat adanya trauma Post Traumatic Stress Disorder yang dialami oleh tokoh Sari. Trauma yang dialami oleh, tokoh Sari mangkibatkan timbulnya stres dan rasa takut untuk keluar dari rumahnya, karena rasa takut tersebut memunculkan bayangan masalalu yang akan membuat tokoh Sari menjadi stres dan ketakutannya menjadi tidak terkontrol.

Berdasarkan analisis data di atas adapun persepektif menurut Skinner tingkah laku seseorang individu akan ikut dengan hukum tertentu yang berlaku pada kehidupannya atau yang kebih dikenal dengan Behavior is lawfull. Peristiwa pembantaian terbunuhnya Ayah dari tokoh Sari merupakan suatu keteraturan peristiwa yang terjadi pada tokoh Sari merupakan peristiwa yang memiliki kerterkaitan secara tertaur dengan peristiwa lainya. Peristiwa tersebut yang menjadi trauma mendalam yang akan dikenang oleh Sari dalam hidupnya (Alwisol, 2016, hal. 338). Pada dasarnya 
setiap individu yang memiliki trauma masa kecilnya, akan takut untuk keluar dari rumahnya dimana ada kecemasan pada kemungkinan bahaya di bayangkan dianganangannya akan terjadi pada saat itu.

Persepektif Freud mengemukakan, jenis kecemasan yang dialami oleh tokoh Sari yang takut untuk keluar rumahnya meupakan jenis kecemasan anxiety, kecemasan ini timbul akibat dri pembantaian yang menwasakn ayahnya yang tertuduh sebagai dukun santet di kampunnya (Alwisol, 2016, hal. 25). Trauma yang dialami oleh suatu individu pada umumnya terjadi saat masa kecilnya, sulit untuk menyesuaikan diri dengan lingkungannya, karena pada tahap adolesen individu mengalami perkembangan kepribadian yang ditandai dengan krisi identitas, yang mengakibatkan titik balik pada peningkatan bahasa dan memuncaknya potensi dari masa krisis yang dialmi tokoh Sari (Alwisol, 2016, hal. 98).

\section{2) Kecemasan Tokoh Sari pada Bahaya yang di jumapai di Masalalunya}

Kecemasan pada suat individu pada umumnya terjadi karean adanya gangguan psikologis yang terjadi karena adanya rasa takut pada hal tertentu.Kcemasan yang terjadi pada tokoh Sari merupakan jenis Kecemasan realistik yang terjdi karena masi Adapun kecemasan yang terjadi pada tokoh Sari sebagai berikut.

Bayangan tentang malam itu hampir selalu berputar dalam ingatan ku. Terus dan terus saja aku seperti itu. Aku jadi tidak dapat berpkir tenang, Aku jadi takut keluar rumah. Aku jadi takut gelap. (Hal. 71)

Pada kutipan data diatas menggambarkan adanya trauma yang selalu datang pada tokoh Sari. Trauma yang terjadi pada tokoh Sari tersebut tidak terlepas dari adanya tingkah laku yang tidak dapat mengontrol pikiranya. Berdasarkan data analisis diatas kemampuan untuk mengntrol tingkah laku dapat dilakukan dengan cara mengantisipasi pikiran-pikiran negatif yang ada didalam otak maupun jiwa. Tingkah laku responden pada tokoh Sari merupakan respon dari stimulus yang melatarbelakangi timbulnya ingatan masalalu tokoh yang kurang baik, sehingga mengakibatkan tingkah laku yang tidak dapat untuk dikontrol dengan baik oleh Sari (Alwisol, 2016, hal. 359).

Sejalan dengan pemarapan di atas adapun pendapat yang dikemukakan oleh, Erikson yang menejelaskan trauma yang dialami oleh setiap manusia memiliki kaitan erat dengan konflik dan peristiwa yang dialami oleh individu tersebut. Misalnya, trauma yan terjadi pada tokoh Sari terjadi karena adanya konflik antara masyarakat yang tertuduh sebagai mengamalkan ilmu santet. Terjadinya konflik pembersihan dukun santet 1998 tersebut membentuk ego karena peristiwa masalalu yang dialami oleh individu tersebut mengakibatkan ingatan tersebut akan mebekas hingga di masa yang akan datang (Alwisol, 2016, hal. 98). Jadi, trauma yang dialami pada individu dapat terbentuk dari adanya konflik yang terjadi pada masalalu yang dialminya, konflik tersebut mengakibat adanya kecemasan realistis yang dialami individu setiap saatnya 
Aku ingat guratan luka yang melingkari leher Bapak entah dari mana hal itu seperti merasuki tubuhku. Aku merasa ada sesuatu dileherku ada yang menjerat tiap kali aku mengingat hal itu. (Hal.72)

Pada kutipan data di atas menggambarkan masalalu yang masi teringat jelas pada ingatan tokoh Sari. Ingatan yangterdapat pada otak Sari tersebut secara tidak langsung mengakibatkan ketidak sadaran yang dialmi tokoh Sari. Perubahan dari tingkah laku yang dialami oleh tokoh Sari tersebut merupakan salah bentuk perubahan diri secara spontan,

Berdasarkan hasil ananlisis diatas berupa adanya stimulus yang terjadi pada tokoh Sari memberikan efek, berwujud dari ingatan pada tokoh Sari yang menimbulkan respon tertentu pada perubahan tingkah lakunya pada kondisis terntentu (Fiest, 2017, hal. 25). Respon yang berasal dari adanya pengalaman di masa kecilnya tersebut mengakibatkan pergolakan batin dan kecemasan pada suatu individu. Pada dasarnya suatu pengalaman pahit yang terjadi pada kehidupan suatu individu akan membentuk suatu ancaman yang setiap saat karena, secara bersamaan pengalaman yang tidak sesuai tersebut masuk kedalam kesadaran.

\section{Bentuk Penguatan Trauma Tokoh Sari}

\section{1) Penguatan Positif}

Ibu sama sekali tidak pernah mengeluh. Dan karenanya aku berusaha melakukan hal yang sama. Sebisa mungkin aku membantu Ibu melakukan pekerjaanya yang seketika menjadi menjadi lebih banyak dua kali lipat setelah bapak meninggal. (Hal.97)

Pada kutipan data diatas merupakan penguatan positif yang terdapat pada tokoh Sari. Penguatan tersebut berasal dari sosok ibunya yang menjadi faktor motivasi bangkit dari segala keterpurukan dan truama yang dialaminya pasca kepergian Bapak nya.

Berdasarkan hasil analisis data diatas faktor penguatan yang ada pada tokoh Sari adalah sosok ibunya karena, menurut Skinner faktor motivasi dalam suatu situasi yang sama dengan tingkah laku bersumber dari berbeda kekuatan dan kseringan munculnya (Alwisol, 2016, hal. 340). Penguatan yang ada pada Sari merupakan wujud dari penguatan positif karena, peristiwa yang dilihat Sari dalam diri ibunya pada kehidupan sehari-harinya membuat Sari secara tidak langsung ingin merubah tingkah lakunya (Alwisol, 2016, hal. 345). Penguatan yang terjadi tersebut secara berangsur akan merubah tingkah laku menjadi lebih baik dengan kemauan dari seorang individu dengan apa yang dikehendaki. 
Ibuku yang penuh keringat ituu membagi senyumnya padaku. Begitulah.Selanjutnya ibu menajadi satu-satunya alasanku untuk keluar dari kamar dan mencoba berperilaku seperti biasanya. (Hal.73)

Pada kutipan data diatas tokoh Sari yang memnipulasi tingkah lakunya dengan penguatan yang bersumber dari ibunya. Penguatan tersebut merupakan pengutan yang memiliki jenis penguatan berkelanjutan yang muncul pada diri tokoh Sari yang berasal dari ibunya.

Berdasarkan hasil analisis data diatas, penguatan berkelanjutan (continous reinforcement) yang setiap kalinya muncul pada tokoh Sari yang dikehendaki oleh dan diberikan oleh reifosemen, karena pada proses penguatan tersebut mengehentikan perilaku sebelmnya dengan perilaku yang dikehendaki dengan mengalami perubahan dan secara perlahan merapkan penguatan tersebut pada keseharianya (Alwisol, 2016, hal. 346).

Proses penguatan yang dialami oleh tokoh Sari untuk Bangkit dari trauma masalalunya pada saat dirinya memberikan penguatan secara tidak langsung diatur berdasarkan perbandingan usaha yang harus dilakukan oleh tokoh Sari. Pada proses penguatan yang dilakukan oleh tokoh Sari harus mendapatkan dukungan sosial yang bersumber dari orang terdekatnya seperti Ibunya dan anggotan keluarganya, karena dukungan sosial merupakan kunci dari kesuskesan yang memegang kendali penting dari terwujudnya penguatan dan kesejahteraan dan kesehatan, baik secara fisik maupun psikologis (Umi, 2014, hal. 244)

\section{2) Penguatan Positif Bersifat Tetap}

Entah kenapa seperti ada dorongan kuat yag menyuruhku datang kesana. Barang kali aku memang berbeda dengan diriku di masa kecil yang begitu ingin menangkap orang-orang yang membunuh Bapak, tapi setidaknya aku masih berharap mungkin disana nanti ada kabar baik apapun itu. (Hal 182)

Pada kutipan data diatas menggambarkan penguatan yang didapatkan dari dorongan dari dalam diri tokoh Sari yang berasal dari superego. Dorongan pada tokoh Sari tersebut, memberikan penguatan yang bersifat berklnjutan dimana, pada penguatan yang dulu pernah ia lakukan dimasa kecilnya tidak mengalami perubahan samapai saat ia dewasa. Berdasarkan analisis data diatas Tokoh Sari yag berusaha memanipulasi tingkah dan perlakuanya karena peristiwa yang membatnya trauma pada kecilnya tersebut berusaha ia hilangkan , untuk memwujudkaan kehidupan dan merubah tingkah lakunnya yang dikehendaki oleh dirinya (Alwisol, 2016, hal. 345). Perubahan tingkahlaku dari tokoh Sari tersebut membuat perkembangan kepribadianya tersebut didapatkan dari faktor internalnya yaitu ibunya. 


\section{SIMPULAN}

Berdasarkan tujuan penelitian terdapat tiga tujuan pertama, menguraikan trauma masalalu yang dialami oleh tokoh Sari. Kedua, mendeskripsikan bentuk trauma yang dialami tokoh Sari. Ketiga, menganalisis bentuk penguatan yang terdapat pada tokooh Sari. Hasil pertama penelitian pertama trauma yang dialami tokoh sari bersumber dar adanya ingatan masalalunya terbunuhnya bapaknya Kedua Sari terdapat dua jenis trauma yang dialami oleh tokoh Sari yaitu, 1) Ketakutan pada dunia luar, 2) Kecemasan pada bahaya yang pernah dialmi pada masalalunya masalalunya.

Ketiga bentuk penguatan yang ada pada diri tokoh Sari yaitu, 1) Penguatan positif, dan 2) Penguatan Positif bersifat tetap. Penguatan yang yada pada diri tokoh Sari didasari adanya pemanipulasian tingkah laku yang tidak dikehendaki, penguatan tersebut bersumber dar Ibunya yang menjadi Faktor Internal perubahan dari tingkah laku tokoh Sari. Adapun dua faktor yang mlatar belakangi trauma yang dialami oleh tokoh Sari yaitu, 1) Pembunuhan , 2) Dsikriminasi. Kedua faktor itu terjadi secara bengsur dan sangat berpengaruh pada trauma yang dialami oleh Sari pada masa kecilnya.

\section{DAFTAR RUJUKAN}

Alwisol, (2016). Psikologi Kepribadian. Malang: UMM Pres.

Association, A. P., (1994). Diagnostic and statistical manual of mental disorder. Fourth Edition ed. Washington DC: Washington DC: Author.

Elisaa, N. E. W. S., (2016). Kajian Psikologi Sastra Dan Nilai Pendidikan Karakter Novel Ibuk Karya Iwan Setyawan Serta Relevansinya Sebagai Bahan Dalam Pembelajaran Bahasa Dan Sastra Indonesia Di SMP. BASASTRA, Volume Vol.4, No.2, pp. 34-44.

Faruk, (2017). Pengantar Sosiologi Sastra. Yogyakarta : Pustaka Pelajar.

Fiest, G. F., 2017. Teori Kepribadian.. Jakarta Selatan : Salemba Humanika .

Hanurawan, F., (2011). Psikologi Sosial Terapan dan Masalah-Masalah Perilaku Sosial. Malang : Fakultas Ilmu Pendidikan Universitas Negeri Malang.

Kohlberg \& L., H. R., (1997). Moral Development: A Review of the Theory. Theory into Practice. Moral Development., Volume 4,2, p. 3.

Nofitra, M. H., (2017). Kajian Psikoanalisis Dalam Novel Pria Terakhir Karya gusnaldi. Jurnal Pendidikan Rokania, pp. 70-89.

Ratna, N. K., (2012). Teori ,Metode,dan, Teknik Penelitian Sastra. Yogyakarta: Pustaka Pelajar.

Rokhmansyah, (2014) . Studi dan Pengkajian Sastra Perkenalan Awal terhadap Ilmu Sastra. Yogyakarta : Graha Ilmu. 
Rokhmansyah, A., (2014). Studi dan Pengkajian Sastra: perkenalan awal terhadap ilmu sastra.. 1 ed. Yogyakarta: Graha Ilmu.

Syifa, L. U., (2015). Dampak Psikologis Tokoh Sumida Yuchi Dan Ma-kun Pasca Gempa Bumi dan Tsunami Sendai 2011 Dalam Film Himizu Karya Sutradara Sono Sion. Skripsi , pp. 1-7.

Tentama, F. ". J. P. U. 1. (. 1.-1., (2014). Dukungan Sosial Dan Post-Traumatic Stress Disorder Pada Remaja Penyintas Gunung Merapi.. Jurnal Psikologi Undip, 13(2), pp. 133-138.

Umi, K., (2014) . Hubungan Dukungan Sosial Dan Trait Kecemasan Dengan Trauma Pada korban Perdangan Manusia. Jurnal Sais Dan Praktik Psikologi, pp. 2(3), 243-255.

Walgito, B., (2010). Pengantar Psikologi Umum. Yogyakarta: Penerbit Andi. 
